\title{
Notes towards a Nietzschean pedagogy of the city
}

\begin{abstract}
Philosophical assumptions about identity, being and belonging have, as is well know, historically been bound together; their classical nexus being Plato's Socrates, who because of this figures as the first philosopher of the city. Especially during moments of crisis, the impulse, both philosophically and politically, even today, is to make abject those who appear not to conform to the appropriate ideal identity of what ought to be. In the first part of our ${ }^{1}$ paper we consider the philosophical logic of this pedagogy of the city and its cultural context and implications; and in the second part, we demonstrate this pedagogy of the city as a practice, using ethnographic data derived from a study of a homeless couple and their struggle to become a family amidst the homeless community within which they live.
\end{abstract}

\section{Key words}

Homelessness, Socrates, agora, abjection, city, ethnography

\section{How the city teaches us, aesthetically}

This is not a pretty paper, nor could it be, given that it is about an awkward and uncomfortable property of being; which is, namely, its metaphysical fabrication. Our paper and the specific slice of being with which it is concerned is even uglier; as we view the fabrication of being from the perspective of its margins, and therefore from the perspective of those who, according to the workings of the established order, barely have the right to be included, and by their very nature are without the right to properly belong.

It may also appear to be somewhat frivolous to align any serious discussion about our education concerning the rights of those who live on the margins, who barely belong and struggle to hold any legitimate identity within the security of the established order, as being anything to do with any kind of theme of aesthetics; with how things should or ought to appear to be. But that is broadly what we are going to do; asserting more or less that, the reason why, particularly at moments of crisis, the impulse of the established order is to abject rather than include those aspects of itself that undermine any metaphysical guarantee of its own establishment and legitimacy, is because of an aesthetic or ideal form, that registers how things should or ought to appear to be. Indeed, if pushed, we would be inclined to argue that the reason of the established order, its symbolic reasoning, which motivates its general actions, is largely organized around this same aesthetic principal. The classical locus for this arrangement is, of course, Plato's Socrates.

\footnotetext{
1 The research for this paper was carried out jointly by myself and XXX; who, despite my best entreaties, has declined to be credited as its joint author; but nevertheless, should this paper ever be favourably regarded, must receive enormous credit for her crucial contribution to the ethnographic aspect of this work, as well as its philosophical analysis.
} 
As is well known, texts from Plato that clearly demonstrate this same impulse to abject those aspects of the state that expose the fabricated nature of an ontological right to be, include the Republic; within which Socrates famously argues that imitative poetry and certain passages in literary and dramatic works, as well as artists who do not support the ideal constitution of the city, should be exiled, since they are false additions to and corruptions of that which is metaphysically meant to be:

If a man who is capable by his cunning of assuming every kind of shape and imitating all things should arrive in our city, bringing with himself the poems he wished to exhibit, we should fall down and worship him as a holy and wondrous and delightful creature, but we should say to him that there is no man of that kind among us in our city, nor is it lawful for such a man to arise among us, and we should send him away to another city, after pouring myrrh down over his head and crowning him with fillets of wood (Plato, Shorey, 1953)

To briefly reprise what has been expertly detailed many times: Socrates' problem is not with the enormous linguistic facility, nor with expertise garnered in any other medium, by any potential Athenian citizen, but with what use any such facility is put to, and only then if that usage and representation is not in a true accord with the ideals of the civic reality around which Athens functions and is sustained. This form of accounting and registering - of accounting for life and registering its propriety, which is to say its right to be, in order for life to have its identity maintained and thereby demarcated within the established order of the city, expressed alongside its vicious compulsion to abject those aspects of being that it regards as not seeming to belong - is primarily an aesthetically motivated pedagogy. It is interesting that historically art has popularly come to be regarded as a contemplative and abstract meditation and representation of something - perhaps a face, a cart abandoned in a river, a woman reading a letter - or some condition or other - such as, a look of love, or abandonment, or the night - as removed from the economy of being (the social economy, the financial economy, the cultural economy, where its worth is actively debated, negotiated, contested, experienced, and so on); so that it might be contemplated in its own space, such as in a gallery, or some part of a landscape. In particular, art tends now to be removed from those aspects of the economy that involve its violence. To clarify and reduce the provocative nature of this argument, we need to separate out from this discussion any idea of depicting violence; so, for example, when we talk about violence we are not specifically interested in whether or not a painting or installation takes as its subject matter a fight, or any similar or different form of dispute. Instead the violence we refer to here, is intrinsic to all forms of art and representation; it is automatic and unavoidable, and is engendered by the wrenching apart of experience from any kind of mimetic intent in relation to that experience. The violence we are interested in, is the violence inherent in the expression of all mimetic intent; that this (a word, or picture, or gesture, or thought, or reflection) represents, and therefore in some way, despite not being that, nevertheless is that, or is some aspect of that as it is revealed to you. It is both the assertion that this represents that, but more 
acutely is the ripping away of this from that, which is ineluctably necessary in any formulation of this in relation to that, which constitutes the violence inherent in all aesthetics of being. All such forms of aesthetic judgement, that this is attempting to be an approximation of that, that this departs from that, in relation to being and being (appropriately) in place, are necessary in order to identify that which does not belong, elements that often will be marked by signs that are thus taken for their difference, and in relation to how things ought to be, for their ugliness, so that they can become abject.

\section{Establishing security through abjection}

William Blake Tyler (2012), drawing on the work of Girard has noted how the fate of Socrates, this first pedagogue of the city, mimics the fate of the pharmakoi at the festival of Thargelia; when representatives of the ugly and the poor, who were without the rights accorded to those for being a citizen, and who were therefore without the right to belong, as if being within the state was determined not politically but by a metaphysical right of being, were first of all fed ostentatiously at public expense, that is at the expense of Athenian citizens, but were then physically abused, in effect scourged, and then led outside the boundaries of the city where they were likely to be killed. The pharmakoi, those without the right to be, who bear all the signs of being outside any system of ideals, and possessing no accord with the metaphysical state of Platonic forms, by their poverty, poor diet, lack of education, chronic exposure to physical and emotional hardship, are also signs of the limitations of any such metaphysical assumption of an order, of an essentially aesthetic nature, of a right to be.

They are the public manifestation, albeit ordinarily confined to the margins of public knowledge and regard, that despite the laws, cultural practices, and modes of thought that support the assumption of Athenian metaphysical being, this is no guarantee against what Lacan refers to as the Real; which in this context is represented by the presence of the poor, which seeps from the margins into civil consciousness, that Athenian society is unable to accommodate. And it is in order to symbolically and literally rid itself of this material and psychic impurity, which undermines the fundamental credibility for the metaphysical order, of the right to be, that the presence of the parasitic pharmakoi are brought to public attention by their ostentatious feeding at public expense, followed by their ritual removal from within the being of the city, so that they can become abject, disposed of; and thus the city becomes cleansed. In much the same way, Athens' reaction to Socrates' pathological compulsion, of publicly demonstrating the epistemological and political vacuity upon which the foundations of Athenian's beliefs, practices and institutions are based, especially during moments of crisis - which, at the time of Socrates' death, is framed by the parlous state of the city following its disastrous involvement and defeat in the Peloponnesian Wars - is analogous to the fate that Plato's Socrates bestows upon those artists, works, practices and others with which he disagrees: they are commonly made abject. And it is in Socrates' condition of finally being made abject by Athens, at his trial and execution, that we are able to see that this is an aesthetic judgment. 
If we remember, we said that an aesthetic judgment was one predicated by the principle that something, this, ought to effectively reference that, where 'effectively reference' is always a political decision about managing a relative conformity, in order to seem to be like that. It is also possible to more easily observe in this example, the violence inherent in all aesthetic judgements, when this does not conform to that mimetic rule, and Socrates is made abject from life, by being poisoned with hemlock as pharmakos by the state, by which means the state is then made clean. As Derrida was very fond of noting (for example, Derrida, 1981) that is always impossible to pin down; principally on account of that, in itself, never being there, or anywhere, in the first place, since that is also always only ever a reference, though a reference privileged by the assumption that it is not so, but is instead the thing, whatever that might be, itself. The common activity that inhabits every aesthetic process is the violence separating, as we have been saying, this from that; and this representation, whatever form it might take, being contingent upon factors beyond its own bearing.

But we should also note another way, the secondary, complementary part of the process that we have just prefaced, that violence inheres to all aesthetic judgments; which is namely through the violence by which all identity is forged, as if it were not so composed, as if it were integral to itself.

Lacan's famous perspective, from which he observes how a child obtains an identity that is meaningful to itself and the seemingly distinct world of others by being registered and sutured to the Symbolic Order (Lacan, 1966) is decisive in this context. The child, or any subject, accedes to the Symbolic Order -the apparently external world of meaning through which their own identity and understanding is mediated - by misrecognizing an image of itself as who they are in their reflection in a mirror. The image in the mirror is, of course, a convenient shorthand for the way that who and what you mean is not determined by some innate precondition of yourself, but is reflected back to you, by the infinite array of other reflections that you receive. Reflections manifested, for example, by carer and non-carer utterances, the behaviours of others, and the intransigent and more yielding encounters that you might have experienced through the physical world around you. Crucially, none of these reflections are you. They are not your expressions. You cannot control them. They do not originate from within, as some authorial testimony to the truth of your unique soul. Though that is what your soul is; that is how your soul is forged. Because outside this alloy of your being, there is nothing else, only your emptiness. This is the Lacanian lack, the desperate, unbearable emptiness at your centre through which you are constituted (Lacan, 1977). They are the reflections of others, collectively of the big Other, the Symbolic Order, which position you, locate you, express your place, and thus compose your identity, so that you can seem to be.

It is the activity of being perceived to be, of regarding, which is the aesthetic practice that determines if, and how, and whether sufficiently this represents that. And it is the violent activity of being regarded by the Other, of this being regarded as that, where otherwise this would be unrecognisable, which shapes the contours of your identity, the nature of your meaning, the level of your 
worth, and the caste of your being. And of therefore whether you have the right to be, as a thing or practice or human subject; of whether you have the right to any life, residing within some space. Indeed, broadly speaking, this is the very condition that residency, ontologically, depends upon.

\section{Forging identity}

If we return once again to the allegations made against Socrates, of denying the city's gods, of adding new gods to the civic pantheon, and corrupting the youth of the city by means of his teaching, it has persuasively more than once been noted that Socrates is guilty, perhaps most famously in The Birth of Tragedy, and in Twilight of the Idols. If we conclude in one sense at least, that Socrates' pathological engagement was with Athens' political forgery of metaphysical truth, as supported by the political function of the city's gods, then there is a clear analogy with the first of the charges brought against him (GiordanoZecharya, 2005). All we need do is substitute Athenian gods for civic virtues and practices, as modes of existence that relate to the immediacy of civic political being, then witness Socrates' relentless and sometimes vicious undermining of their credibility. In contradistinction to this contingent, imperfect and thus, from a metaphysical point of view, essentially flawed practice (Taylor, 2007), the philosophical knowledge that Socrates advocated was derived, according to Socrates, from the voice of God, rather than being fabricated through the mediations of the city environment. This is not the religious perspective of the Athenian polis. This represents a fundamental difference between on the one hand, the politics of being a citizen, resulting in the assumption of the ontological status of being a citizen, along with any of its accompanying rights and obligations, as a matter of civic regard; and on the other hand, the ontological status and rights that would seem to be the assumption of a private interiority, by the assumption of being able to carefully regard one's self. Socrates' God does not announce His intensions and presence, and therefore His allegiance, or so it could be argued on political grounds, to Athens in general; but only to a single member of its polis, namely Socrates; where otherwise divine order normally translates as state intention and presence, as evoked, for example, in public and domestic rituals and festivals. But no, this God whispers in Socrates' psychic ear alone, so that apart from through Socrates, no one else can hear or know this philosophy of the divine. And similarly, surely the very point of teaching such things, is to publicly expose their contingent and inferior political nature when identified as their relation to a metaphysical virtue that, given the ideal and therefore enduring nature of its perfection, can only be mimetically approached in life. And, it is when civic virtue and politics in general is identified as being in relation to metaphysical virtue that their nature appears to be intrinsically corrupt. By contrast, civic virtue and politics, as being in relation to itself, that is to say, as contingent behaviours in relation to the immediacy of circumstance, cannot be corrupt. From this perspective, you do not have to look very far to see why Socrates has been associated with death, whilst the work of his best known critic, Nietzsche, has been characterised as an iconoclastic affirmation of life (see, for example, Reginster (2006) as but one commentary amongst almost the general consensus of all). Socrates' incessant teaching requires Athenian's to put 
aside the immediacy of their engagement with the affairs of the city, and its politically organized forms of being, as well as those aspects of the self that promote the politics of the ego; especially so if this identity of the self is stitched into cultural and other forms of aggrandizement.

But before we are allowed the much more comfortable judgment, that Socrates was primarily concerned with the moral order of Athenian society and the transparent probity of its operations, which is, of course, true, any such comfortable judgement elides its origins and the motivation behind Socrates' incessant critical attention. These origins and motivation are found in the conviction that life, specifically the civic life of Athens, is inferior to the eternal, divinely ordered existence, of which Socrates' has been uniquely afforded glimpses and insights; glimpses and insights that form the divine inspiration of his pedagogy, the pedagogy of the city. So let us, for a moment, suspend the over-determination of moral right that is always the given, a priori condition, from which Socrates' position proceeds, as if it were his (and perhaps it is this combination of personal moral conviction, derived from the interiority of one's self, from one's soul, as Socrates describes it, that is his enduring originality). From this perspective, it is much more obvious that Socrates' is at best unconcerned with the immediacy of the present moment; he suspends or even derides the contingent relations that such immediacy and unpredictably engender; that is to say, he reduces life, except in preparation for its end and death. As F.C. White amongst many others has noted, Socrates "... believes with as much certainty as is possible that he will be with gods who are in every way good masters... and he confidently believes that there is a life to come, a life to come moreover... [that is] much better for the good than for the wicked" (White, 2006: 447). Indeed, so great is Socrates' personal conviction that, “... all who engage worthily in philosophy will follow him [Socrates] in death as soon as possible" (White, 2006: 447). This is a conviction that for the worthy, death brings a condition that is better than being alive; where the worthy are those who lead a life as determined by Socrates' philosophy, which Socrates denies as being his, claiming that such philosophy is simply channelled through him, as God's representative.

What lies, in both senses of this word, at the empty heart of this conviction, empty because it seems barren to the disordered contingency and imperfection of lived communal experience, is the determination of purity and power. White (2006) is hardly alone in making this point, especially in relation to the Phaedo and the other texts that deal explicitly with Socrates's trial and last days. For example, Warnek (2005) carefully identifies Socrates' preoccupation with being itself, and its continuity with thought itself, and with truth itself; a consequence of which is the identification of sensual, corporeal, emotional and political being as pollutants, corruptions and distractions from the transcendence of ontology itself; such that Socratic philosophy marks a radical caesura in the development of Western thought. A caesura according to which the body and its situated being is then intellectually and pragmatically abandoned. And of this abandonment, this making abject we note this crucial point: 
Within the relatively narrow confines of classical Greek philosophy and society, what we have witnessed is not the pure and simple domination of the established order, whether constructed as a metaphysical guarantee of epistemological and spiritual truth framed as the Platonic ideal, or as the determination by the legislative mechanisms of the Athenian polis of what the proper conduct and teaching of its citizenry ought, and ought not, to be; both instances of which, we have argued, are aesthetic judgements, determined by their respective forms of regard; and both of which lead to the abjection of each by the other. Whilst we have argued that it is the power of the assumption of the established order that inevitably, in any form of contest, and particularly viciously so during moments of crisis, renders that which does not mimetically conform, abject, whether the example is the discordant practices of everyday life, the pharmakoi, or the body; they are, we believe, all characterised within this schema by their contingent existence as opposed to metaphysical assumption. But since the metaphysical guarantee of the right to be and the right to belong is no real guarantee at all, being instead an exercise in the power to determine, such a guarantee is dependent upon the extent, which is also to say, the limit, of its force. Within the field of what has become human experience, the power to determine can be crushing, but never complete. It may be contested by conscious and unconscious circumstance, by its own fabricated nature, by limitations in its investment, by lethargy and enthusiasm alike, by the unaccountable nature of contingent existence. And so what we observe, in the social ontology of our daily lives, and particularly at its margins, and during moments of crisis, is a persistent vacillation, an unending movement from identities and practices that are held in place by a metaphysical assumption, which is always on the side of the established order, allied to Lacan's Symbolic Order; but through their encounter with contingent experience, their innate fragility, their exposure as being forged, incomplete, redolent with the limitation of being, uncovered and subject to the bleak finality of what Nietzsche understood as life. And, again, there are obvious similarities here with Girard's (1987) analysis of scapegoating. Of course, the over-riding impulse of the established order, its reason, is to cover over any cracks that appear, to abject the contingent which does not belong, to seal up ruptures in fabricated being, to close its borders, police the perimeter by which it is defined. But this pathological condition of the established order is never able to rid itself of the vacillation between an identity's metaphysical assumption and its exposure to the fabrication of its contingent being.

\section{An ethnography of the city's pedagogy}

The onto-cultural practices we have so far briefly reviewed in relation to the abjection of those aspects of the established order it deems do not belong, are of course essentially redemptive in their motivation and orientation. The figure of Jesus Christ and the establishment of the Roman Catholic Church are other famous examples that comfortably sit within this same nexus of crisis, abjection and redemption. But this essentially conservative impetus, characterized by a tendency to reassert the enduring, transcendent, metaphysical assumptions that structure the cultural practices and predispositions of an established order is not 
the only - though it may be the predominant and most powerful - response available. As Sal Flavel has recently pointed out:

'Nietzsche's "death of God" refers to a moment of profound upheaval within European culture. The death of God represents not only the demise of the Christian deity, but also the destruction of all absolute conceptions of reality, truth, and the good: those metaphysical values that have sustained philosophy in the West since Plato.' (Flavel, 2015: 12)

But whereas Flavel interprets any Nietzschean demonstration of the absolute hollowness of metaphysics as an opportunity '... to open itself up to dialogue with traditions of thought that had previously been characterized only in terms of their irreducible difference' (Flavel, 2015: 13); instead, what we have been inclined to predominantly observe is the more consistent impetus for the abject bodies of any established order to at the most, contest their right to have some kind of presence in the public space of the Agora, in whatever form that might take, before being marginalised in ways against which they appeared to have little if any control. We could illustrate this contemporary tendency of the Nietzschean pedagogy of the state to abject those bodies that do not belong, through the current refugee crisis, and would argue that at the moment, we are witnessing, in the West, if at all possible, a second 'death of God'; so that we seem to have killed God twice, which is quite an achievement in relation to the immortal being of all time, represented by not only the economic and political destabilization of Europe, or at least very specific parts of Europe, but also by the massive disruption in parts of Africa and the Middle East. But instead, we would like to trace this same movement at a much more local level, by drawing on recent ethnographic research we have undertaken with a group of chronically homeless people in Chester. In particular, we want to focus on a homeless couple, Joe and Sal, who had hoped to become a family. At the time we were conducting research, Sal was seven months pregnant. Before, however, we proceed any further, we would like to add a caveat:

The assumption of metaphysical being, that things are as they are because they are necessarily so, with that form of being expressing a model of lived experience, such as might find its analogue in the model of the traditional nuclear family, or the role of the mother, or father, or the virtues and behaviour of an Athenian citizen or contemporary British or any other national identity, however loosely interpreted is not a matter of choice or idiosyncratic construction. They are the assumptions by which identity is forged; and however impermanent, fragile or idiosyncratic any such identity might be, there is no alternative by which any onto-epistemic identity might come to be. From the perspective of the established order, however, a perspective that bleeds into the identities of those who do not belong, the being of those who exist on the margins appears to be much more contingent in nature, and especially so when their bodies are made abject. What we propose to do for the remainder of the paper is to trace with you a single morning that we accompanied Joe and Sal from the Day Centre into the city, drawing attention in particular to the way that identities shuttle unceasingly between the assumptions of metaphysical and contingent being: in many ways, it is typical of the lives of this abject community. 
When we arrived outside the Day Centre at around ten in the morning, Joe was very animated and loud, and was standing with a few friends away from the main group of homeless people, including Sal. Sal explained that Joe was a bit agitated (and very pleased with himself): he had just been released from the local custody suite, having been detained over-night following a police raid at about ten-thirty during the previous evening on the temporary accommodation where they were being housed by a local charity. That temporary housing was provided by a local charity, and not the Local Authority, which acts as the local representative of the state, is highly significant in this context, and is continuous with the politics of mimetic desire drawing on Girard's work, especially when applied to the state, as we have described in relation to Socrates' teaching and Athens. Sal was assured by the Local Authority that if she applied for housing on her own, as a single mother-to-be, then she would be housed as a priority. Not only were Sal and her unborn child at risk, because she was homeless; their vulnerability, and hence the urgent need to find them appropriate housing, was increased because of Sal's mental health issues and her history of addiction and substance abuse. Sal did not, however, want to be identified through the regard of the Local Authority, which functions in this context as an aspect of the Symbolic Order, as a single mother. She and Joe wanted to be a couple, to be regarded as an expectant family, and to belong within this normalised symbolic matrix, and thereby accrue all of the rights and investments that members of the community of the family would normally expect to quite naturally follow. Joe's own criminal record, and history of addiction and substance abuse precluded the Local Authority from regarding Joe and Sal as a couple, much less an expectant family; and so in this guise, of family-to-be, they were unrecognized by the state, and were quite literally refused accommodation. Onto-politically, they were made abject, since mimetically they did not legitimately belong, according to the reason of the established order. It is therefore very significant that it was a local charity that was able to provide Sal and Joe with temporary accommodation, since by definition they operate outside the auspices of the state, specifically ministering to the needs of those that the state fails to regard, according to the aesthetic and mimetic principles that we have described. And it is especially significant in terms of traditional Roman Catholic theo-logical reasoning, which, in its designation of the Holy Family, the Family that will come to represent the ontological guarantee of all lived ontic family experience, inverts the figure of the family made abject, the family that does not belong, has no place to be, by providing shelter outside what would otherwise be recognized as legitimate habitation. Again, what we are clearly able to observe in the structure of this symbolic arrangement, is the vacillation between identities that conform to an aesthetic principle guaranteed by the authority of the established order, and contingent experience that lacks the necessary investment within the same order for any such place to be maintained; and that this is a dynamic rather than fixedly determined process, is demonstrated in the way that the Church, and in this case the work of a charity, recuperates the abject family, transforming it into a symbol of salvation.

At a more micro individual behavioural level, it is by understanding this philosophical dynamic and the logic of abjection, that we are able to appreciate the degree of feeling that animated Joe that morning, and why he was in such an 
intensely oppositional and ebullient mood. The size of the police operation that had been mounted on the house, during which, late at night, the police had sealed off both ends of the road where the house was sited, and had entered the property with dogs, signalled an overwhelming display of force by the established order to abject those who did not belong. This was both a physical and symbolic attempt to police the border separating those with the right to be from those whose identity, for whatever reason, did not conform to the legitimate mimetic order of being. And yet, despite the size of the operation and the extensive nature of the search, nothing had been found, and Joe had been released without charge. The onto-local-logical position, if we think of the 'local' component of this clumsy neologism as designating the symbolic and geographical place of the right to be, at this point was doubled and contradictory. On the one hand, Joe was regarded by the established order as existing at best along its margins, with intense attempts by its representatives, in the guise of the Local Authority and the police, to expel him from its proper domain of being. It was against this regard that Joe vigorously protested his right to be, as the expectant father and head of a family-to-be, thus vociferously declaring his belief in having an identity that legitimately belonged within the established order. On the other hand, the fact that the police had failed to find anything during their search, and had been forced to release Joe intensified his own - quite momentary - triumph over the established order, and its attempts to render him abject, which also confirmed his - momentary - identity as being victoriously oppositional to the same order about which he was also claiming the right to belong. Again, this is typical of the movement of being, of the oscillation between symbolic and contingent identity.

Soon after, we and the rest of the group moved along the short and well-known route from the Day Centre into the heart of the city, to an area known as the Cross. The Cross is historically and contemporaneously a very significant public space, and functions, because of this, in a way similar to that of the Athenian agora. Allen (2002) explains how the classical Athenian agora, the principle public space within the city, functioned as the locus of the requirement of being present in order to register the onto-juridical right of one's identity as having the right to be for any Athenian citizen during this period. So that, for example, minor transgressions of Athenian law might result in a citizen not being allowed into the agora for a limited period of time; so that during this time, they were quite literally absent, taking no part in the social economy of being. Not being, that is to say, not being a citizen, and therefore not being regarded as such by those who belong, carried with it rights that literally determined the capacity to be, i.e. to live, for one's self. We can see this in the escalation of punishments that were appropriate for citizens guilty of more severe transgressions of the law; with greater crimes being punished with a citizen not only being barred from entering the Agora, but also the name of the person not being allowed to be mentioned, in order that even this form of their representation was removed during this period; to ever more severe cases where former citizens might be permanently exiled, or executed, with their names being struck from public records, their houses and property being raised and expunged from existence, 
and any monuments, bearing reference to their being, destroyed, their presence materially obliterated from circulation in the economy of public memory.

Originally deriving its significance as the cross roads of the city, the Cross grew to be a civically designated meeting place and place of religious worship, and thus over time grew in importance, as signified by the historical monument erected there, also known as the Cross, as well as it developing into being the commercial heart of the city. With Chester now deriving most of its income from tourism, the cultural and therefore commercial value of the Cross as a civic space has intensified. It is one of the key areas in the city where tourists and organized tours gather. The businesses around the Cross, including shops and restaurants, are financially dependent upon this space and how it is occupied. The Cross is also one of the most significant spaces within the city for its community of homeless people. Part of its significance for homeless people is much like the agora in classical Athens: it is a place through which the social economy of one's being is registered and made present; it is a place to be, to be seen and recognized, in public, in common. And there are other features of this area that in practical ways confirm its significance specifically for homeless people. For example, behind the Cross, Saint Peter's Church has a drop in area, which provides physical shelter from the outside as well as minimally priced drinks and food; there are benches outside, at the Cross, which are extremely important if you have no place of your own to sit and rest; the Cross is surrounded by a series of covered alleys, above street level, called the rows, which are relatively quiet and provide shelter from bad weather. For all of these reasons, the Cross has also become an area where homeless people meet, socialise, and move off from, for various reasons, including to score drugs, and generally socialise. It is also, given the different kinds of investments that we have just described in the area that are specific to the different populations that we have sketched, not unnaturally very much a contested space; with its contestation registered electronically through the high levels of CCTV in and around the Cross, linked directly to the police. On the particular morning in early summer that we have been recalling, there were large numbers of Japanese sight seers on an organised tour gathered in the area.

It was also a particularly hot day. We sat on the benches with Sal, Eddie and a number of others, whilst Joe's ebullient and oppositional mood intensified. Given the context, this was not unpredictable, especially when a community support police officer appeared. Joe proclaimed loudly to the community support police officer, that whilst he was about to be a father, indicating Sal on the bench, he had to endure a police raid on his house, was taken away, kept over-night, then released without charge; by comparison the Japanese tourists, who were not even from this country, were being allowed to gather in large numbers at the Cross, and were not even being questioned by the police, let alone seemed likely to be told to move on. Joe's response to the context is entirely continuous with the process of oscillation between what we have described as symbolic being, which is always allied to the established order, and the experience of contingent being, which exists between the cracks in the identities that forge the assumption of a metaphysical reality. It was again his appeal to the traditional role of the father, by which he sought the right to 
independently identify himself with the legitimacy of the established order, and the refusal of the order to accept this as part of his legitimate identity and therefore his right to belong, which both motivated and enraged Joe; especially in relation to the Japanese tourists; and especially in the location of the Cross, the contested public space, that appeared always available to those who were, in Joe's eyes, overtly foreign and therefore, according to his logic of outrage, should not be granted the right to belong. It was also significant that the official representing the established order was a community support police officer, and not a police officer. Community support police officers are immediately identifiable as such, and are viewed very much by the homeless community as 'pretend' or 'fake' or 'baby' police officers; their status is often demeaned because their identity is regarded as forged, as not being real. Indeed, Joe also pointed this out to the community support police officer who was present at the Cross. In many respects, this was a point about the construction and undermining of assumed metaphysical identity in relation to the city, which is not dissimilar to Socrates' teaching about the epistemic and ontological pretence of Athenian civic life.

As Joe's encounter with the community police officer intensified, Eddie noted that he was in danger of being arrested; again, there are also parallels in this respect with Socrates; and in order to avoid Joe's removal by the police, Eddie made the following intervention. He left the benches where we were sitting and, approaching Joe and the community support police officer, explained that Sal was struggling in the increasing heat of the day, and since there was no shade at the Cross, suggested it would be better if we all moved off to the nearby precincts of the Cathedral, which was a much more pleasant and sheltered environment from the sun, and probably for Sal, was an altogether healthier place to be, as the heat mounted. Eddie's tactical exploitation of symbolic identity and the behaviours that accompany it, in this case the act of sacrificing and rising above self-interest in order to take care of one's partner and unborn child, thereby disengaging from the bind of contingent experience that appeared to be heralding Joe's immanent arrest, is also inextricably bound to the physical and social contours of the city, through which the economy of identities come to be forged.

Once within the relative shade of the benches behind the Cathedral, the group, including, Joe and Sal, began to role and smoke joints; nevertheless, even though this is an activity that we might assume falls outside notions of expectant parenting that are consistent with the established order, it was not regarded as such by those present. Indeed, what immediately followed prompted Sal to assert the importance of a commitment to respecting parental roles and the need for others to display behaviours that supported rather than undermined good parenting. This was motivated by the appearance of Sam. As Sam approached, Eddie commented that he was probably looking for his coat, having forgotten that Eddie had earlier agreed to look after it for him. This caused Sal to say that even though Sam provided amusement for the group, by means of his disorganization and forgetfulness, this behaviour was in fact not funny but actually irresponsible. She went on to explain that only recently, they too had volunteered to help Sam by storing some of his things at the house where they 
were staying, one item of which included his coat. Unfortunately, as was typical of Sam, he had forgotten to remove the drugs and drug paraphernalia, including, she claimed a needle, syringe and heroin that he had some time earlier been to score. This would have been bad enough, but what made it worse was that Joe was an ex-heroin user: staying clean is always very hard, but much more so at times of stress, and this was an extremely stressful period with Joe about to be a father. There is no doubt that what Sal said was true.

We had met Sam the previous day, without any of the others, when he had stopped to speak to us on the benches at the Cross. He told us that he had just tried to kill himself, by hanging, but that his huddie, which he had used in the attempt, had ripped. Sure enough, the garment was damaged. He then asked to borrow thirty-six pence, which would give him enough money to buy a sausage roll from the pound Bakery, before intending to move off to end his life at the viaduct. We were glad the following day to see him alive. Unfortunately Sam has, for some time now, disappeared from view. Rumours abound about what has happened to him in relation to a drug debt. We would like to dedicate this paper to the hope that they are not true.

\section{References}

Derrida, J (1981) Plato's pharmacy. Dissemination (trans. Barbara Samson) London: The Athlone Press, 61-172

Giordano-Zecharya, M (2005) As Socrates shows, the Athenians did not believe in gods. Numen, Vol. 52, No. 3, 325-355

Girard, R (1986) The scapegoat. Baltimore: The Johns Hopkins University Press

Lacan, J (1966) Écrits. Paris: Éditions du Seuil

Lacan, J. (1977) The mirror stage as formative of the function of the I as revealed in psychoanalytic experience. In Écrits: A Selection. Trans. Alan Sheridan.

London: Tavistock Publications Ltd.

Plato (1953) The Republic. Trans. Paul Shorey. Cambridge Mass.: Harvard University Press

Reginster, B (2006) The affirmation of life: Nietzsche on overcoming nihilism. Cambridge: Harvard University Press

Taylor, C (2007) From the whole citizen body? The sociology of election and lot in the Athenian democracy. Hesperia: The Journal of the American School of Classical Studies at Athens, Vol. 76, No. 2, 323-345

Tyler, WB (2012) The sacrifice of Socrates: Athens, Plato, Girard. Michigan: Michigan State University Press 
Warnek, P (2005) Descent of Socrates: self-knowledge and cryptic nature in the Platonic dialogues. Indiana: Indiana University Press

White, FC (2006), Socrates, philosophers and death: two contrasting arguments in Plato's Phaedo. The Classical Quarterly 56; 2: 445-458 